\title{
Evaluation of Land Use Planning, Transport Scenario with Reference to Express Highways in and Around Hyderabad City, Telangana
}

\author{
P. Chandra Shekhar ${ }^{1}$, Dr. Talla Manorama Kumari ${ }^{2}$, V. Venkateswara Reddy $^{3}$ \\ ${ }^{1}$ Research Scholar, JNTUH, Hyd \\ ${ }^{2}$ Assistant Professor, Civil Engg Dept, Moulana Azad National Urdu University, Gachibowli, Hyd \\ ${ }^{3}$ Professor, Civil Engg Dept, JNTUH, Kukatpally, Hyd.
}

\begin{abstract}
Transport planning is intrinsically linked to land use planning and both need to be developed together in an integrated manner. In developing such plans, attention should also be paid to the future growth of the city. Transport plans should, therefore, enable a city to take an urban form that best suits the geographical constraints of its location and also one that best supports the key social and economic activities of its residents.
\end{abstract}

Keywords: Land Use, Transport, Express Highways, GIS.

\section{Introduction}

The Transportation concept is one such growth/ development strategy to assist the City in implementing the guiding principles of the Land Use Element. In the TOD strategy, new moderate and high density housing as well as new public uses and a majority of neighbourhood-serving retail and commercial uses will be concentrated in mixeduse developments located at strategic points along the regional transit system. This linkage between land use and express highways is designed to result in an efficient pattern of development that supports a regional transit system and makes significant impact in reducing traffic congestion and urban sprawl.

The mixed-use of land for residential and commercial activities, designed to minimize the need for transport and maximize the access to public transport, and often incorporates features to encourage transit ridership. A neighbourhood typically has a centre with a train/transit station, metro station, monorail station, tram stop, or high capacity bus stop, surrounded by relatively high-density development with progressively lower-density development spreading outwards from the centre.

\section{Study Area}

Hyderabad City is situated in the river Musi and Krishna basin, which is a tributary of river Krishna, passes through the city and bifurcates it into Northern and Southern Hyderabad. It is situated between 78022'30" \& 78032'30" east longitude \& between 17018'30" \& 17028'30" north latitude. The ground levels vary from 487 meters to 610 meters above mean sea level (B.Purushothama Reddy 2004).

\section{Land Use Management}

According to LU.LC map, the proposed residential use is $46.05 \%$. The proposed usage under public and semi-public zone is $10.10 \%$ and makes a total of $14.84 \%$ including $4.83 \%$ of defence area. A total area of 8.8 sqkm constituting $5.10 \%$ has been proposed under Multipurpose use zone. As per statistics, this zone comprises the existing mixed development areas, commercial hubs, residential, commercial and public and semi-public usages. Including rocks and hillocks a total of 12.7 sq.km constituting $7.36 \%$ of total area has been proposed under Open spaces, parks and playgrounds. A total area of 20.52 sq. km constituting $11.49 \%$ has been proposed under transportation land use category. 


\section{International Journal of Science and Research (IJSR) \\ ISSN (Online): 2319-7064}

Index Copernicus Value (2016): 79.57 | Impact Factor (2015): 6.391

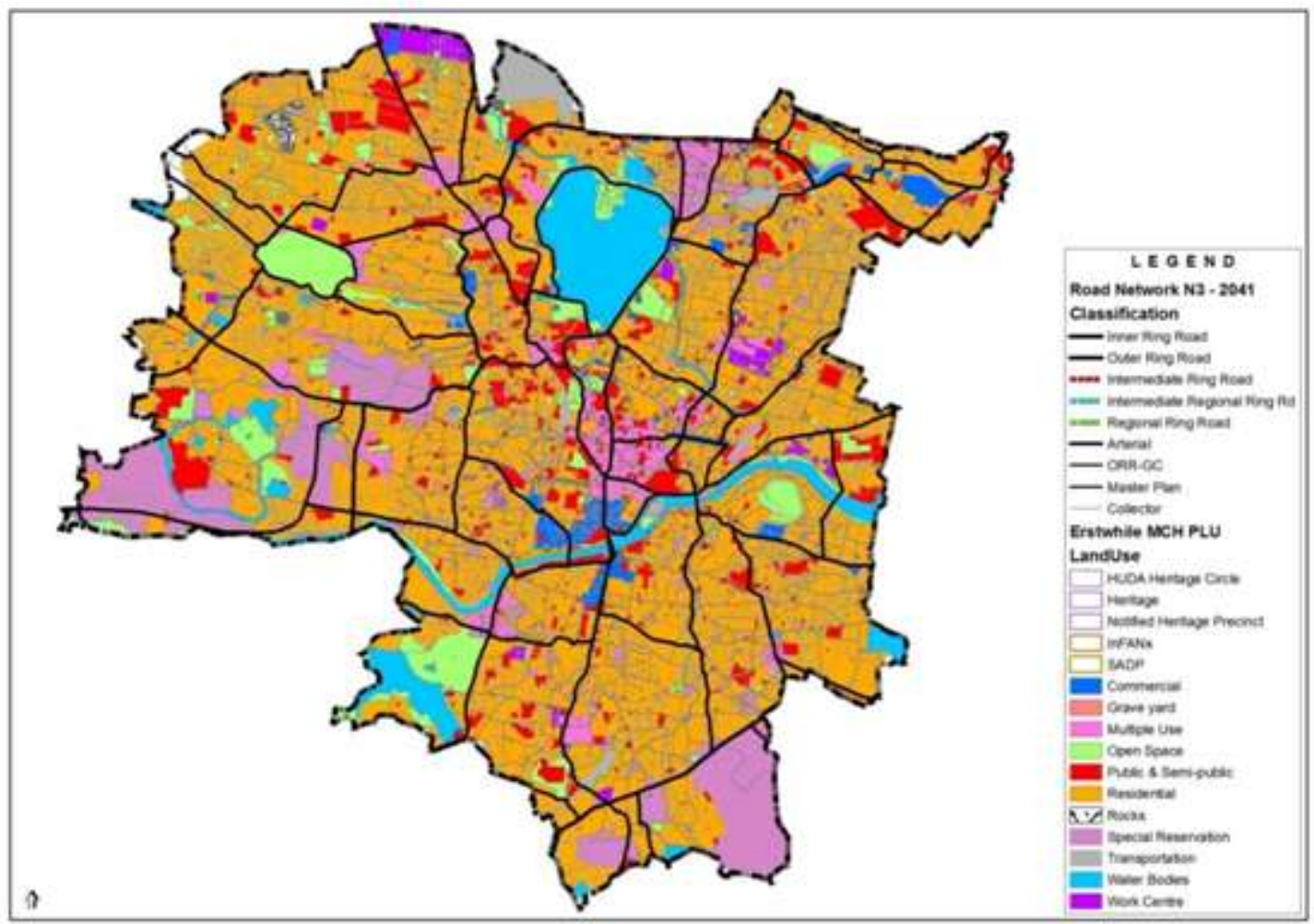

Figure 1.1: Land Use Land Cover Map of Hyderabad City

Source: Hyderabad Metropolitan Development Authority (HMDA)

Table 1.1: Land Use Classification of the study area

\begin{tabular}{|c|c|c|c|}
\hline Sl. No. & Land Use & Area in Sq.km & $\%$ \\
\hline 1 & Residential & 79.48 & 46.05 \\
\hline 2 & Commerclal & 9.49 & 5.5 \\
\hline 3 & Multiple use & 8.80 & 5.10 \\
\hline 4 & Industrial (Including manufacturine, small scale, household, garages etc) & 2.76 & 1.60 \\
\hline 5 & Public Semi public & 17.43 & 10.10 \\
\hline 6 & Parks \& Playgrounds, Recreation & 12.70 & 7.36 \\
\hline 7 & Water Bodies (River, Lakes, Nalahs, Kuntas) & 10.75 & 6.23 \\
\hline 8 & $\begin{array}{l}\text { Transportation \& Communication (Includes major Roads \& Circulation, Airport, Bus } \\
\text { Stations/Depots. Rly Tracks/Stns, Excludes internal colony roads, streets, Pathways etc) }\end{array}$ & 19.83 & 11.49 \\
\hline \multirow[t]{3}{*}{9} & Special Reservations & & \\
\hline & (a) Burlal Grounds Crematoria etc & 3,00 & 1.74 \\
\hline & (b) Defence & 8.34 & 4.83 \\
\hline \multicolumn{2}{|r|}{ Total } & 172.59 & 100 \\
\hline
\end{tabular}

Source: Hyderabad Metropolitan Development Authority (HMDA)

\section{Landuse Planning and Options (Express Highways Options)}

As part of the long term transportation strategy with reference to land use is alternative options. Each of these alternatives will give a different set of distributions for the planning parameters. It is to be noted that employment distribution has been further disaggregated in office, industrial, agricultural, and other worker's categories in all the scenarios.

The first scenario (Trend Based) assumes that population and employment distribution at the cluster level will be based on past growth trends observed. The outcome of this method is highly dependent on the available time series data. Cluster level population for 2041 is distributed based on the trends observed in the 1991- 2001 and 2001-2011 decades and employment distribution is based on base year data and a series of assumptions.
The second scenario (Master Plans) involves distribution of population and employment based on the various master plans in HMA (Core Area, Rest of HUDA area, and Extended HMA area). The 2031 and 2041 population projected based on extrapolation of the master plan data works out to be 26.9 million and 35.7 million respectively for HMA.

The third and fourth scenarios involve distribution of population and employment based on appropriate weightages given to factors such as availability of land for development and accessibility by various modes of transit and transport. This approach is termed as land use and transport scenario. The land use/transport based approach is based on the underlying principle that the spatial distribution of additional population in the study area will depend on transport network options (accessibility) and land use (including concentration of population and employment at growth centres). This scenario also helps us identify clusters with higher potentials for development.

\section{Volume 6 Issue 12, December 2017}




\section{International Journal of Science and Research (IJSR) \\ ISSN (Online): 2319-7064 \\ Index Copernicus Value (2016): 79.57 | Impact Factor (2015): 6.391}

The additional population and employment in these two scenarios are distributed based on weights assigned to each of the selected criteria. The parameters identified for the allocation of additional population and employment to the clusters are: lengths of bus route network, metro and other transit network, express highways, national highway, state highway, and all other existing and proposed major (4 lane and above) roads that pass through the cluster, number of potential growth centres areas and existing land uses. Such considerations are taken to employ and achieve population and employment distribution for future years based on the concept of Transit Oriented Development (TOD).

For the purpose of long term planning a series of growth centres have been identified in all areas from the core to the outer ring road growth corridor-the urban nodes and urban centres as proposed in the recently approved master plan for the extended area have been retained.

\section{References}

[1] Anji Reddy M, 2005, "Environmental Geoinformatics and Modelling"; Proceedings of International Conference on Environmental Management, B.S. Publications.

[2] B.Purushothama Reddy 2004, Director, House Numbering cell, Municipal Corporation of Hyderabad, The GIS Friendly Environment in Urban and Municipal Governance - A case study of Andhra Pradesh.

[3] B.Purushothama Reddy and et al 2011, intelligent house numbering system, published in geospatial today.

[4] D.P.Tiwari, Challenges in Urban Planning for local bodies in India, I.A.S., Commissioner \& Director, Town and Country planning, Bhopal.

[5] FAO, 1989 : Guidelines of Land Use Planning. FAO of the united Nations, Rome.

[6] Manual of Land use / Land cover mapping using Satellite imagery", Part I and II 1989, National Remote Sensing Centre, Department of Space, Govt. of India.

[7] National Urban Information System 2006 (NUIS0 Scheme, Guidelines for Implementation by Town \& Country planning Organisation, Ministry of Urban Development, Government of India.

[8] Prof. Anjana Vyas and Et.al 2004, School of Planning, Cept, Ahmedabad, can RS and GIS be a policy instrument for urban local Governements.

[9] Revised Development Plan (Master plan) 2010, of Erstwhile Municipal Corporation of Hyderabad Area (HMDA Core Area) by Hyderabad Metropolitan Development Authority, Govt. of Andhra Pradesh.

[10] Thomas M. Lillesand and Ralph W. Keifer 2000, Remote sensing and Image interpretation, Fourth Edition, John Wiley and Sons, Inc, New York

Volume 6 Issue 12, December 2017 www.ijsr.net 